\title{
Kepemimpinan Lurah dalam Meningkatkan Motivasi Kerja Perangkat Kelurahan
}

\section{Leadership of Village Leaders in Enhancing Job Motivation of Kelurahan Device}

\author{
Boby Arianto*, Warjio**, Usman Tarigan*** \\ *Pemerintah Kabupaten Deli Serdang \\ **Fakultas Ilmu Sosial dan Ilmu Politik, Universitas Sumatera Utara, Indonesia \\ *** Fakultas Ilmu Sosial dan Ilmu Politik, Universitas Medan Area, Indonesia \\ Corresponding author: E-mail: Bobbyarianto23@yahoo.com
}

\begin{abstract}
Abstrak
Penelitian dengan memfokuskan pada Bagaimana kepemimpinan lurah dalam meningkatkan motivasi kerja perangkat bagaimana tingkat motivasi kerja perangkat serta bagaimana upaya yang dilakukan lurah dalam hal meningkatkan motivasi kerja perangkat. Dalam penelitian ini penulis menggunakan metode penulisan dengan metode penelitian yang bersifat deskriptif dengan pendekatan induktif. Setelah dikaji berdasarkan keadaan di Kelurahan Lubuk Pakam I-II dapat diketahui bahwa kepemimpinan lurah dalam meningkatkan motivasi kerja perangkat kelurahan dengan cara pemberian motivasi kepada para perangkat, dengan tujuan meningkatkan motivasi kerja, mengetahui tingkat motivasi kerja perangkat kelurahan, upaya yang dilakukan lurah dalam meningkatkan motivasi kerja dengan cara meningkatkan tingkat kesejahteraan perangkat, menciptakan suasana kerja yang harmonis, memberikan penghargaan atas prestasi kerja, bersikap adil, menghormati dan mengikutsertakan perangkat, melengkapi fasilitas kerja, mengembangkan potensi, pemberian hukuman atau sanksi, kepemimpinan lurah dalam meningkatkan motivasi kerja perangkat kelurahan sangat didukung oleh instansi pemerintah yang terkait untuk menerima dan mengaktualisasikannya dalam meningkatkan motivasi kerja perangkat di Kelurahan Lubuk Pakam I-II. Dalam penelitian ini dapat disimpulkan bahwa kepemimpinan lurah dalam meningkatkan motivasi kerja perangkat dikategorikan baik dan diharapkan untuk selanjutnya dapat mengatasi semua hambatan yang ada dalam meningkatkan motivasi kerja perangkat di Kelurahan Lubuk Pakam III.
\end{abstract}

Kata Kunci: Kepemimpinan Lurah, Motivasi Kerja, Perangkat, Organisasi, Lubuk Pakam.

\begin{abstract}
Research by focusing on how lurah leadership in improving the work motivation of the device how the level of work motivation of the device and how the efforts made by the village head in terms of increasing the work motivation of the device. In this study the authors use the method of writing with research methods that are descriptive with an inductive approach. After being studied based on the situation in Kelurahan Lubuk Pakam I-II it can be seen that the leadership of urban village in improving the motivation of the kelurahan by giving the motivation to the tool, with the aim of increasing the work motivation, knowing the level of work motivation of kelurahan, the effort done by the lurah in increasing the motivation work by increasing the level of welfare of the device, creating a harmonious working atmosphere, rewarding work performance, being fair, respecting and including tools, completing work facilities, developing potentials, giving punishment or sanctions, lurah leadership in enhancing motivation of kelurahan by the relevant government agencies to receive and actualize it in improving the work motivation of the device in Lubuk Pakam I-II Urban Village. In this research, it can be concluded that the leadership of lurah in improving work motivation is categorized well and expected to further overcome all obstacles that exist in improving the work motivation of the device in Lubuk Pakam I-II.
\end{abstract}

Keywords: Leadership of Lurah, Work Motivation, Device, Organization, Lubuk Pakam.

How to Cite: Arianto, B., Warjio, Usman T., (2016), Kepemimpinan Lurah dalam Meningkatkan Motivasi Kerja Perangkat Kelurahan, Jurnal Administrasi Publik, 6 (2): 107-122. 


\section{PENDAHULUAN}

Berlakunya Undang-Undang Republik Indonesia Nomor 23 Tahun 2014 tentang Pemerintah Daerah, diharapkan memberikan dampak nyata yang luas terhadap peningkatan kinerja terutama kedisiplinan aparatur dalam mengemban tanggung jawab dan tugasnya. Pelimpahan wewenang dari Pemerintah Pusat ke Daerah memungkinkan terjadinya penyelenggaraan pemerintahan dengan jalur birokrasi yang lebih ringkas dan membuka peluang bagi Pemerintah Daerah untuk melakukan inovasi dalam penyelenggaraan pemerintahan di daerah.

Hal ini membawa dampak yang sangat signifikan terhadap beban, tugas dan tanggung jawab Pemerintah Daerah Otonom. Salah satu dampak yang telah dilakukan adalah penataan sistem pelayanan umum, sebagai tujuan utama dari undang-undang tersebut. Sistem pelayanan umum pemerintah, akan tercapai manakala diiringi peningkatan kualitas sumber daya manusia aparatur, sarana dan prasarana, serta perangkat pelayanan umum lainnya yang terarah, terpadu, dan terkoordinasi.

Otonomi daerah itu sendiri adalah kewenangan daerah otonom untuk mengatur dan mengurus kepentingan masyarakat setempet menurut prakarsa sendiri berdasarkan aspirasi masyarakat, sesuai dengan peraturan perundang-undangan. Untuk mengimplementasikan makna otonomi daerah tersebut secara luas, nyata, dinamis, dan bertanggung jawab, pemerintah Kabupaten/Kota dituntut untuk mampu meningkatkan Pendapatan Asli Daerah, yang merupakan salah satu sumber utama pembiayaan dalam penyelenggaraan tugastugas pemerinahan, kemasyarakatan, dan pembangunan.

Dua hal pokok di atas, yaitu pelayanan umum dan pengembangan potensi daerah dalam meningkatkan pendapatan asli daerah, bukan rahasia lagi bahwa yang sangat berperan adalah kehidupan organisasi yang dinamis, dan tentunya tidak terlepas dari manusia sebagai pelaku utama dari organisasi tersebut. Eratnya hubungan antara tujuan organisasi dengan manusia, sangat berkaitan dengan fungsi manajemen dalam merencanakan, menggerakkan, mengarahkan, dan mengelola sumber daya manusia, agar mampu bekerja sepenuh hati.

Untuk terlaksananya dan suksesnya seluruh kegiatan yang ada dalam organisasi maka peranan kepemimpinan seorang pemimpin yang disebut dengan top manager harus dapat menggerakkan dan memanfaatkan potensi kekuatan yang ada atau kemampuan yang dimiliki oleh para pegawai, karena kepemimpinan merupakan inti dari pada managemen dan sekaligus merupakan motor atau daya penggerak dari pada semua sumber dan alat-alat yang tersedia bagi suatu organisasi baik itu sumber manusia dan seperti metode, material dan pemasaran (S.P. Siagian,1983). Disisi lain seorang pemimpin harus mempunyai pengetahuan yang luas tentang organisasi yang dipimpinnya dan pemimpin harus memiliki keahlian managerial (managerial skill) yang berhubungan dengan tugas - tugas pemimpin yaitu memberikan arahan petunjuk perintah dan pengawasan terhadap tugas - tugas yang dilaksanakan oleh para pegawai bawahannya. Seorang pemimpin harus memiliki kepemimpinan atau leadersip yang baik sesuai dengan situasi dan kondisi organisasi yang dipimpinnya.

$$
\text { Menurut Undang-Undang Republik }
$$
Indonesia Nomor 5 Tahun 2014 tentang Aparatur Sipil Negara disebutkan bahwa Pegawai Negeri Sipil sebagai unsur aparatur negara yang bertugas untuk memberikan pelayanan kepada masyarakat secara profesional, jujur, adil, dan merata dalam penyelenggaraan tugas negara, pemerintahan dan pembangunan. Maka pegawai sebagai pelaksana tugas - tugas pemerintahan langsung harus memiliki profesionalisme dan motivasi kerja yang tinggi untuk melaksanakan tugas - tugas tersebut.

Dari uraian di atas peranan kepemimpinan seorang pemimpin sangatlah 
menentukan dan mempengaruhi motivasi kerja pegawai agar terdorong nalurinya untuk berbuat dan berkerja dengan prestasi yang tinggi. Berbagai pendapat ahli mengemukakan bahwa ada beberapa tipe kepemimpinan antara lain tipe kepemimpinan militeristis, tipe kepemimpinan otokratis dan tipe paternalistis (Kartini Kartono, 2011) yang ketiga tipe ini sangat mendekati dengan persamaan tipe kepemimpinan formal karena ketiga tipe ini di dalam memotivasi pegawainya lebih menitikberatkan pada kekuasaan dan perintah sesuai dengan kehendak pemimpin agar para bawahannya mutlak harus patuh pada perintahnya dan para pegawai bekerja secara rutinitas sesuai dengan tata kerja dan mekanisme kerja yang ada di dalam organisasi.

Untuk menggerakkan bawahannya pemimpin harus dapat memposisikan dirinya sebagai motivator yaitu harus mampu mendorong atau mempengaruhi bawahannya untuk berkerja secara optimal. Berkaitan dengan motivasi sebagaimana yang di definisikan oleh para ahli bahwa motivasi adalah proses atau faktor yang mendorong orang untuk bertindak atau berperilaku dengan cara tertentu (Moekijat, 2003:5). Dorongan atau pengaruh tersebut datangnya dari naluri setiap bawahan untuk memenuhi kebutuhan dasar yang diinginkannya, apabila hal tersebut terpenuhi maka setiap orang akan merasa senang dan sukarela untuk melakukan sesuatu tugas atau pekerjaan yang diembannya. Dari pengertian motivasi tersebut dapat dikemukakan bahwa motivasi kerja adalah suatu pengaruh gaya kepemimpinan terhadap bawahan agar berkerja secara sadar dan senang tanpa adanya suatu paksaan dari pimpinan. Motivasi kerja sangat berhubungan dengan kinerja, jika motivasi kerja lemah maka kinerja juga akan menurun, bawahan akan cepat bosan dalam menghadapi tugas, kurang inisiatif dan juga kurang kreatif, yang mana hal ini merupakan pencerminan rasa ketidakpuasan pegawai terhadap kepemimpinan atasan. Gaya kepemimpinan yang tidak tepat, akan melemahkan motivasi kerja pegawai, hal ini akan berdampak kepada rendahnya kinerja.

Berkaitan dengan motivasi kerja ini, Kelurahan Lubuk Pakam I-II yang berada di bawah Kecamatan Lubuk Pakam Kabupaten Deli Serdang, dimana di pimpin seorang Lurah yang merupakan Kepala pemerintahan di kelurahan, serta memiliki perangkatperangkat kelurahan, diantaranya termasuk kepala-kepala lingkungan dan perangkat lainnya. Kelurahan sebagai level pemerintahan yang berada di bawah camat, tentunya menginginkan jalannya organisasi sesuai dengan yang diamanatkan dalam semangat otonomi daerah. Akan tetapi dalam pelaksanaannya masih banyak terdapat kekurangan yang sangat signifikan dari para pegawai kelurahan yang tercermin dari sikap dan perilaku. Oleh karena itu sangat perlu membina dan memperhatikan semangat kerja perangkat kelurahan, agar mampu mendukung Pemerintah Daerah Kabupaten Deli Serdang, dalam mengimplementasikan otonimo daerah tersebut.

Lurah sebagai pemimpin organisasi pemerintah memegang peranan kepemimpinan yang sangat penting dalam menentukan dan meningkatkan kinerja dari aparatnya menuju suatu paradigma pemerintahan yang baru. Penyelenggaraan pemerintahan di Kelurahan ditentukan oleh kemampuan Lurah sebagai pimpinan bersama dengan para stafnya sebagai pelaksana tugastugas.

Namun demikian sampai saat ini sebagian opini masyarakat bahwa manajemen Pemerintah Kelurahan khususnya Kelurahan Lubuk Pakam I-II belum dapat melayani kebutuhan masyarakat secara optimal. Di sisi lain opini sebagian besar masyarakat menyatakan bahwa masih banyak pegawai pemerintah kelurahan terkesan bukan pelayan masyarakat tetapi sebagai orang yang minta dilayani. Hal ini ditandai apabila masyarakat memerlukan pelayanan, harus melalui prosedur yang berbelit-belit dan kadang- 
kadang melanggar norma-norma yang telah ditetapkan.

Kinerja dan motivasi perangkat kelurahan Lubuk Pakam I-II, dalam melaksanakan tugas dan tanggung jawabnya sebagai abdi masyarakat, yang membantu dalam memberikan pelayanan kepada masyarakat belum dilaksanakan secara maksimal, di sebabkan karena ketidaksiapan dan juga kemampuan para perangkat kelurahan belum dimiliki secara obyektif. Dilihat pada kedisiplinan para perangkat kelurahan dalam menjalankan tugasnya juga belum diterapkan dengan baik oleh para perangkat kelurahan. Kedisiplinan Lurah yang lemah dalam mengawasi atau mengontrol pelaksanaan tugas yang dikerjakan oleh para perangkatnya menyebabkan kinerja dan motivasi dari para perangkat kelurahan tersebut tidak dapat ditingkatkan. Hal tersebut dilihat dari kekosongan para perangkat kelurahan pada jam-jam kerja atau para perangkat yang pulang lebih awal sebelum jam kerja berakhir. Sehingga masyarakat yang membutuhkan bantuan pelayanan publik tidak dapat mengurus keperluan mereka butuhkan, karena tidak adanya perangkat yang bertugas dalam bidangnya untuk membantu masyarakat tersebut.

Kepemimpinan Lurah Lubuk Pakam I-II, perlu bersikap lebih proaktif dan tegas terhadap para pegawai/perangkat kelurahan, beliau dapat lebih mengenal dan memahami kondisi para perangkat untuk lebih meningkatkan kinerja dan motivasi untuk dapat mencapai tujuan organisasi yang diinginkan. Peningkatan motivasi para perangkat kelurahan Lubuk Pakam I-II masih harus terus ditingkatkan agar dalam memberikan pelayanan kepada masyarakat dapat dilakukan secara maksimal dan dapat mengerjakan suatu tugasnya dengan waktu yang relatif cepat, serta menghasilkan kualitas layanan yang memuaskan. Dengan demikian Lurah Lubuk Pakam I-II harus lebih dapat lagi meningkatkan motivasi kerja perangkat kelurahan nya, Faktor yang sangat mendukung kepeimpinan Lurah dalam meningkatkan motivasi kerja perangkat kelurahan dapat dilihat dari cara lurah tersebut memperhatikan kebutuhan-kebutuhan yang diperlukan oleh para perangkat kelurahannya, untuk dapat lebih meningkatkan motivasi kerjanya agar dapat mencapai tujuan organisasi yang diinginkan.

Kepemimpinan Lurah sangat
mempengaruhi banyak hal dalam penyelenggaraan pemerintahan di Kelurahan termasuk diantaranya perilaku dan kinerja perangkat dalam melaksanakan tugasnya, prestasi kerja dari pegawai kelurahan, tingkat disiplin pegawai di kantor Kelurahan dalam memberikan pelayanan kepada masyarakat. Kepemimpinan yang tepat akan mendorong timbulnya kesediaan bawahan untuk berbuat dan berperilaku sesuai dengan apa yang dikehendaki oleh pimpinan. Berkaitan dengan penyelenggaraan pemerintahan Kelurahan, pegawai kantor Kelurahan dalam kapasitasnya sebagai aparatur pemerintah Kelurahan merupakan unsur pelaksana utama tugastugas Lurah yang ada di wilayah Kelurahan. Berhasil tidaknya tugas-tugas Lurah sangat ditentukan salah satunya dari kinerja para pegawai di kelurahan tersebut.

\section{METODE PENELITIAN}

Peningkatan kinerja merupakan aspek yang penting bagi suatu organisasi yang membangun keunggulan bersaing melalui peran sumber daya manusia yang menjalankan strategi organisasinya. Oleh karena itu sangatlah penting peran seorang pemimpin dalam mendorong semua pegawai untuk memberikan kontribusi secara optimal terhadap pencapaian tujuan organisasi.

Suradinata (2010:11) mengatakan bahwa: "Kepemimpinan adalah kemampuan seorang pemimpin utuk mengendalikan, mempengaruhi pikiran, atau tingkah laku orang lain dan untuk mencapai tujuan yang telah ditentukan sebelumnya".

Banyak pendapat mengatakan bahwa kepemimpinan itu dilahirkan bukan dibuat, 
ada pula yang mengatakan bahwa kepemimpinan itu timbul karena situasi yang mendorong. Namun pada umumnya teori-teori kepemimpinan berusaha menerangkan faktorfaktor yang memungkinkan munculnya kepemimpinan dan sifat dari kepemimpinan itu.

Dari kerangka pemikiran diatas dapat dihipotesiskan bahwa: 1) Seorang pemimpin memiliki pengaruh yang besar dalam meningkatkan motivasi pegawai melalui cara kepemimpinannya. 2) Motivasi kerja berpengaruh secara signifikan terhadap kinerja pegawai.

Sebelum mengetahui jumlah populasi dan sampel yang ditetapkan pada penelitian ini, terlebih dahulu akan dikemukakan tentang pengertian populasi dan sampel. Menurut Sugiyono (2010:57) menyatakan bahwa: Populasi adalah wilayah generalisasi yang terdiri atas objek/subjek yang mempunyai kuantitas dan karakteristik tertentu yang ditetapkan oleh peneliti untuk dipelajari kemudian ditarik kesimpulannya.

Populasi menurut Arikunto (2011:102), adalah "keseluruhan subjek penelitian". Dengan kata lain populasi adalah merupakan keseluruhan unit yang dilengkapi dengan ciriciri permasalahan yang diteliti.

Dalam penelitian ini penulis mengambil populasi yaitu seluruh perangkat kelurahan di Kantor Kelurahan Lubuk Pakam I-II Kecamatan Lubuk Pakam, dan jumlah penduduk yang secara tidak langsung mempengaruhi kinerja Kelurahan Lubuk Pakam I-II antara lain: 1) Aparat Kelurahan Lubuk Pakam I-II sebanyak 17 orang, 2) Masyarakat di Kelurahan Lubuk Pakam I-II sebanyak 8340 orang.

Menurut Arikunto (2011:109), sampel merupakan "Sebagian atau wakil populasi yang diteliti". Sedangkan menurut Nazir (2009:221) sampel adalah sebagian dari populasi yang diambil dan dipergunakan untuk menentukan ciri dan sifat yang dikehendaki oleh populasi.
Adapun sampel dari penelitian ini adalah: 1. Sekretaris Lurah $=1$ orang, 2 . Kepala Seksi Umum $=1$ orang, 3. Kepala Seksi Pemerintahan $=1$ orang, 4 . Kepala Seksi Kesejahteraan Sosial $=1$ orang, 5. Kepala Seksi Keamanan dan Ketertiban $=1$ orang, 6. Kader $\mathrm{PKK}=2$ orang, 7. Kepala Posyandu $=1$ orang, 8. Kepala Lingkumgan $=11$ orang, Jumlah $=19$ orang

Teknik pengumpulan data dengan cara mengajukan daftar pertanyaan kepada responden yang berhubungan dengan masalah penelitian. Kuesioner ini diberikan kepada seluruh perangkat kelurahan Lubuk Pakam I-II dan pamong-pamong kelurahan dari tingkat RT, RW, kepala lingkungan serta organisasi yang terkait dengan kelurahan.

Wawancara (interview) yaitu mengadakan tanya jawab (face to face) dengan pihak perusahaan yang mempunyai wewenang untuk memberikan informasi/ data yang dibutuhkan dalam penelitian ini.

Dokumentasi, Pengumpulan data dengan berbagai sumber dokumen / arsip yang berhubungan dengan pelaksanaan penelitian.

Pengamatan (observasi), observasi adalah teknik pengambilan data dengan mengamati langsung fenomena di tempat penelitian. Jenis observasi yang dilakukan adalah observasi non partisan yaitu penulis tidak melakukan aktivitas yang mempengaruhi obyek yang diteliti.

$$
\text { Hadi dalam Arikunto (2011:94) }
$$

mengatakan bahwa "Variabel sebagai gejala yang bervariasi”. Berkaitan dengan hal ini, maka Arikunto mengemukakan bahwa dalam variabel penelitian ada dua hal yang perlu diperhatikan, yaitu sebagai berikut: 1) Sifat Variabel, ditinjau dari sifatnya, variabel penelitian dapat dibedakan menjadi dua, yaitu variabel statis dan variabel dinamis. 2) Variabel statis adalah variabel yang tidak dapat diubah keberadaannya, misalnya jenis kelamin, status sosial ekonomi, tempat tinggal dan lain-lain. 3) Variabel dinamis, adalah variabel yang dapat diubah keberadaannya berupa pengubahan, peningkatan atau 
penurunan, misalnya kedisiplinan, motivasi, kepedulian, pengaturan dan sebagainya.

Hubungan Variabel, ditinjau dari hubungan dalam hal ini keterkaitan antara objek yang akan diteliti variabel dalam penelitian ini dibagi menjadi dua bagian: 1) Variabel bebas, yaitu variabel yang dapat mengalami perubahan dalam hal ini bisa berupa kenaikan atau penurunan. 2) Variabel terikat, yaitu variabel yang tidak dapat mengalami perubahan walaupun dalam kurun waktu tertentu. 3) Variabel dalam penelitian ini terdiri dari 1 variabel bebas (Kepemimpinan Lurah) dan 1 variabel terikat (Motivasi Kerja).

Dari definisi konsep di atas, penulis menggunakan variabel kepemimpinan lurah dalam meningkatkan motivasi kerja perangkat kelurahan di Kelurahan Lubuk Pakam I-II Kecamatan Lubuk Pakam Kabupaten Deli Serdang, maka landasan operasional yang digunakan berdasarkan dua variabel yaitu : 1) Kepemimpinan Lurah dengan Indikator sebagai berikut : Meningkatkan kesejahteraan perangkat kelurahan; Menciptakan suasana kerja yang harmonis; Memberikan penghargaan atas prestasi kerja; Bersikap Adil; Menghormati dan Mengikutsertakan.; Melengkapi Fasilitas Kerja; Mengembangkan Potensi; Pemberian Hukuman. 2) Peningkatan Motivasi Kerja dengan indikator sebagai berikut: Motivasi kerja; Hasil pekerjaan:

Bogdan dan Taylor dalam Moleong (2010:103) mndefinisikan "analisis data sebagai proses yang merinci usaha secara formal untuk menemukan tema hipotesis (ide) seperti yang disarankan oleh data dan sebagai usaha untuk memberikan bantuan pada tema dan hipotesis itu". Moleong (2010:103) "menyimpulkan bahwa analisa data merupakan proses penyusunan data agar dapat ditafsirkan". Menyusun data berarti menggolongkan data, pola, kategori, dan satuan uraian dasar sehingga dapat ditemukan tema dan dapat dirumuskan hipotesis kerja seperti yang disarankan oleh data.
Penulis melakukan penyusunan data dengan menggolongkan data lalu menganalisis data dan membandingkan data lain yang relevan secara deskriptif dengan pendekatan induktif.

Guna mencapai hasil analisis yang akurat dan relevan maka penulis melakukan langkahlangkah analisis data sebagai berikut: 1) Reduksi Data, yaitu dengan memilih data-data yang berhubungan dengan obyek penelitian, dan difokuskan pada hal-hal yang penting guna mempertajam pusat perhatian; 2) Display data, yaitu membuat bagan struktur dan tabel terhadap data yang telah diperoleh selama melaksanakan penelitian; 3) Membuat kesimpulan, yaitu menarik kesimpulan terhadap data yang telah diperoleh selama melaksanakan penelitian.

Untuk memudahkan dalam menganalisa data, maka digunakan standarisasi data sebagai berikut: 1) Penentuan Kualitatif Jawaban. Menurut Nazir (1999:445), ada tiga altematif jawaban yang diberikan kepada responden dan telah ditentukan kualitas jawabannya dengan bobot nilai tertentu, yaitu: Untuk jawaban huruf a, dengan bobot nilai 3 (tiga); Untuk jawaban huruf $b$, dengan bobot nilai 2 (dua); Untuk jawaban huruf c, dengan bobot nilai 1 (satu). 2) Penentuan Persentase, menurut Ali (1997:15), untuk menentukan persentase adalah dengan menggunakan rumus sebagai berikut :

Persentase $(\%)=$

$\frac{\text { Frekwensi Jawaban }(f)}{\text { Banyaknya Re } \operatorname{Rponden}(n)} \times 100 \%$

Penentuan Kriteria Hasil Skor (x), kriteria jawaban dari responden dapat ditentukan dari variabel-variabel yang tergolong kurang, cukup baik, dan bak Oleh karena itu ditentukan terlebih dahulu skala intervalnya. Menurut Nazir (1999:445) untuk menyatakan tingkat interval, digunakan rumus:
Interval (I) =
Jadi skala intervalnya adalah 


$$
\begin{gathered}
\frac{\text { Jarak Pengukuran }(R)-1}{\text { Jumlah Kelas }} \\
\mathrm{I}=\frac{R}{K}=\frac{3-1}{3}=0,66
\end{gathered}
$$

Jadi kriteria jawaban dari responden dapat kita tentukan melalui variabei-variabel sebagai berikut :

\begin{tabular}{ll}
\hline Interval & Kriteria \\
\hline $1,00-1,66$ & Kurang \\
$1,67-2,33$ & Cukup Baik \\
$2,34-3,00$ & Baik \\
\hline
\end{tabular}

Penentuan Hasil Skor Akhir :

Skor(x)

$\underline{N(\text { Interval }) x F(\text { Banyak Re sponden })}$ $F($ Jumlah Re sponden $)$

\section{HASIL DAN PEMBAHASAN}

Berdasarkan hasil wawancara penulis dengan Bapak Budiaman Sagala selaku Sekretaris Lurah Kelurahan Lubuk Pakam I-II pada tanggal 21 April 2016 di Kantor Kelurahan Lubuk Pakam I-II bahwa Lurah menggunakan gaya kepemimpinan yang demokratik untuk melaksanakan tugasnya.

Agar motivasi bawahan dapat ditingkatkan maka pemimpin harus dapat menerapkan kepemimpinan yang sesuai dengan situasi dan kondisi yang ada, kepemimpinan mengandung dua pengertian yaitu gaya kepemimpinan yang diterapkan dan upaya-upaya pemimpin dalam membina motivasi kerja perangkat kelurahan.

Motivasi kerja yang rendah dari para pegawai akan mengakibatkan terhambat atau tidak tercapainya tujuan organisasi sebagaimana yang diharapkan. Demikian juga sebaliknya, dengan keadaan motivasi aparat yang tinggi maka kondisi ini akan mendukung tercapainya tujuan menjadi sasaran dari suatu organisasi.

Menurut S/ Pamudji (1993 : 124) gaya kepemimpinan demokratik yaitu pemimpin yang memandang manusia adalah mahluk yang bermartabat dan harus dihormati hakhaknya, kemampuan pengikut, menghindarkan diri dari penggunaan paksaan dan tekanan.
Dalam gaya kepemimpinan demokratik pimpinan senang menerima saran, pendapat atau kritik dari bawahan. Beberapa kepemimpinan lurah dan meningkatkan motivasi kerja Perangkat kelurahan diantaranya sebagai berikut: 1) Meningkatkan kesejahteraan perangkat kelurahan; 2) Menciptakan suasana kerja yang harmonis; 3) Memberikan penghargaan atas prestasi kerja; 4) Bersikap adil; 5) Menghormati dan mengikutsertakan; 6) Melengkapi fasilitas kerja; 7) Mengembangkan potensi; 8) Pemberian hukuman

Meningkatkan Tingkat Kesejahteraan, untuk mengetahui bagaimana kepemimpinan Lurah Lubuk Pakam I-II dalam meningkatkan kesejahteraan di lingkungan organisasi Kelurahan, dapat dilihat pada tabel 9. sebagai berikut :

Tabel 9. Tanggapan Responden Mengenai Kepemimpinan Lurah Dalam Meningkatkan Kesejahteraan

\begin{tabular}{llllll}
\hline No. & $\begin{array}{l}\text { Alternatif } \\
\text { Jawaban }\end{array}$ & $\mathrm{N}$ & $\mathrm{F}$ & $\mathrm{N} \times \mathrm{F}$ & Persentase \\
\hline 1. & Baik & 3 & 13 & 39 & 68,42 \\
2. & Cukup Baik & 2 & 6 & 12 & 31,58 \\
3. & Kurang & 1 & - & - & - \\
\hline Jumlah & 6 & 19 & 51 & 100,00 \\
\hline Skor : $51 / 19=2,68$ & & & \\
Kategori : Baik
\end{tabular}

Sumber : Data Olahan Kuisioner No. 1, 2016

Berdasarkan tabel di atas dapat diketahui bahwa kepemimpinan Lurah Lubuk Pakam I-II dalam meningkatkan kesejahteraan perangkat kelurahannya dengan frekwensi yang mengatakan baik sebanyak 13 orang $(68,42 \%), 6$ (enam) orang yang mengatakan cukup baik (31,58\%), dan tidak ada yang mengatakan kurang, sehingga diperoleh skor (x) sebesar 2,68 yang termasuk dalam kategori baik.

Menciptakan Suasana Kerja Yang Harmonis, untuk mengetahui bagaimana kepemimpinan Lurah Lubuk pakam I-II dalam meningkatkan suasana kerja yang harmonis di lingkungan organisasi kelurahan, dapat dilihat pada tabel 10. sebagai berikut : 
Tabel 10. Tanggapan Responden Mengenai Kepemimpinan Lurah Dalam Menciptakan Suasana Kerja Yang Harmonis

\begin{tabular}{llllll}
\hline No. & $\begin{array}{l}\text { Alternatif } \\
\text { Jawaban }\end{array}$ & $\mathrm{N}$ & $\mathrm{F}$ & $\mathrm{N} \times \mathrm{F}$ & $\begin{array}{l}\text { Persenta } \\
\text { se }\end{array}$ \\
\hline 1. & Baik & 3 & 12 & 36 & 63,15 \\
2. & Cukup Baik & 2 & 7 & 14 & 36,85 \\
3. & Kurang & 1 & - & - & - \\
\hline Jumlah & 6 & 19 & 50 & 100,00 \\
\hline Skor : $50 / 19=2,63$ \\
Kategori : Baik
\end{tabular}

Sumber : Data Olahan Kuisioner No. 1, 2016

Dari tabel di atas, terlihat bahwa kepemimpinan Lurah Lubuk Pakam I-II dalam menciptakan suasana kerja yang harmonis dilingkungan organisasi kelurahan, termasuk dikategorikan baik dengan 2,63. Dimana situasi dan kondisi kerja yang ada akan mempengaruhi motivasi kerja perangkat, serta situasi dan kondisi lingkungan kerja yang baik akan dapat menumbuhkan atau dapat meningkatkan motivasi kerja perangkat tersebut.

\section{Memberikan Penghargaan Atas}

Prestasi Kerja, Kepemimpinan Lurah Lubuk Pakam I-II dalam memberikan penghargaan bagi perangkat kelurahannya yang berprestasi, dapat dilihat pada tabel 11 sebagai berikut:

Tabel 11 Tanggapan Responden Mengenai

Kepemimpinan Lurah Dalam Memberikan

Penghargaan Atas Prestasi Kerja

\begin{tabular}{|c|c|c|c|c|c|}
\hline No. & $\begin{array}{l}\text { Alternatif } \\
\text { Jawaban }\end{array}$ & $\mathrm{N}$ & $\mathrm{F}$ & $\mathrm{N} \times \mathrm{F}$ & Persentase \\
\hline 1. & Baik & 3 & 11 & 33 & 57,89 \\
\hline 2. & $\begin{array}{l}\text { Cukup } \\
\text { Baik }\end{array}$ & 2 & 8 & 16 & 42,11 \\
\hline 3. & Kurang & 1 & - & - & - \\
\hline \multicolumn{2}{|c|}{ Jumlah } & 6 & 19 & 49 & 100,00 \\
\hline
\end{tabular}

Sumber : Data Olahan Kuisioner No. 1, 2016

Berdasarkan tabel di atas, terlihat bahwa Kepemimpinan Lurah Lubuk Pakam I-II dalam memberikan penghargaan kepada perangkat kelurahannya termasuk dalam kategori baik dengan skor 2,57. walaupun bentuk penghargaan yang diberikan tersebut terkadang hanya berupa ucapan terima kasih, pujian atau pengakuan secara wajar terhadap keberhasilan yang telah dicapai, namun kepemimpinan tersebut cukup berhasil dalam menumbuhkan motivasi kerja dan rasa bangga dari dalam diri perangkat kelurahan untuk selalu berusaha meningkatkan hasil kerja yang akan dicapai. Karena di samping itu keberhasilan yang dicapai akan menjadi catatan sebagai atasan langsung terhadap prestasi kerja dalam DP-3.

Bersikap Adil, Kepemimpinan Lurah Lubuk Pakam I-II dalam memberikan keadilan kepada semua perangkat kelurahannya, dapat dilihat pada tabel 12. sebagai berikut:

Tabel 12. Tanggapan Responden Mengenai

Kepemimpinan Lurah Dalam Memberikan Keadilan

\begin{tabular}{|c|c|c|c|c|c|}
\hline $\begin{array}{l}\mathrm{N} \\
\mathrm{o}\end{array}$ & $\begin{array}{l}\text { Alternatif } \\
\text { Jawaban }\end{array}$ & $\mathrm{N}$ & $\mathrm{F}$ & $\begin{array}{l}\mathrm{Nx} \\
\mathrm{F}\end{array}$ & Persentase \\
\hline $\begin{array}{l}1 . \\
2 . \\
3 .\end{array}$ & $\begin{array}{l}\text { Baik } \\
\text { Cukup Baik } \\
\text { Kurang }\end{array}$ & $\begin{array}{l}3 \\
2 \\
1\end{array}$ & $\begin{array}{l}1 \\
5 \\
4 \\
-\end{array}$ & $\begin{array}{l}45 \\
8 \\
-\end{array}$ & $\begin{array}{l}78,94 \\
21,06 \\
-\end{array}$ \\
\hline & & 6 & $\begin{array}{l}1 \\
9\end{array}$ & 53 & 100,00 \\
\hline
\end{tabular}

Skor : $53 / 19=2,78$

Kategori : Baik

Sumber: Data Olahan Kuisioner No. 1, 2016

Dari tabel di atas, terlihat bahwa kepemimpinan Lurah Lubuk Pakam I-II dalam memberikan keadilan kepada perangkat kelurahannya, termasuk dalam kategori baik dengan skor 2,78.

Menghormati dan Mengikutsertakan, Kepemimpinan Lurah Lubuk Pakam I-II di dalam menghormati dan mengikutsertakan perangkat kelurahannya, terutama pengambilan keputusan, dapat dilihat pada tabel 13, sebagai berikut:

Tabel 13. Tanggapan Responden Mengenai

Kepemimpinan Lurah Dalam Menghormati Dan Mengikutsertakan Perangkat Kelurahan

\begin{tabular}{llllll}
\hline No. & $\begin{array}{l}\text { Alternatif } \\
\text { Jawaban }\end{array}$ & $\mathrm{N}$ & $\mathrm{F}$ & $\mathrm{N} \times \mathrm{F}$ & Persentase \\
\cline { 1 - 5 } 1. & Baik & 3 & 16 & 48 & 84,21 \\
2. & Cukup & 2 & 3 & 6 & 15,79 \\
3. & Baik & 1 & - & - & - \\
\hline Jumlah & 6 & 19 & 54 & 100,00 \\
\hline
\end{tabular}

Skor : $54 / 19=2,84$

Kategori : Baik

Sumber: Data Olahan Kuisioner No. 1, 2016 
Dari tabel di atas, dapat dilihat bahwa kepemimpinan Lurah Lubuk Pakam I-II dalam menghormati dan mengikutsertakan perangkat kelurahannya, termasuk dalam kategori baik dengan skor 2,84.

\section{Melengkapi Fasilitas Kerja,} Kepemimpinan Lurah Lubuk Pakam I-II di dalam melengkapi fasilitas kerja di kantor kelurahan antara lain melengkapi sarana kerja yang secara langsung dibutuhkan dalam melakukan pelayanan kepada masyarakat. Pada tabel 14 di bawah ini menunjukkan kepemimpinan Lurah di Kelurahan Lubuk Pakam I-II dalam melengkapi fasilitas kerja di kantor kelurahan.

Tabel 14. Tanggapan Responden Mengenai

Kepemimpinan Lurah Dalam Melengkapi Fasilitas Kerja

\begin{tabular}{|c|c|c|c|c|c|}
\hline No. & $\begin{array}{l}\text { Alternatif } \\
\text { Jawaban }\end{array}$ & $\mathrm{N}$ & $\mathrm{F}$ & $\mathrm{N} \times \mathrm{F}$ & Persentase \\
\hline $\begin{array}{l}1 . \\
2 . \\
3 .\end{array}$ & $\begin{array}{l}\text { Baik } \\
\text { Cukup } \\
\text { Baik } \\
\text { Kurang } \\
\end{array}$ & $\begin{array}{l}3 \\
2 \\
1\end{array}$ & $\begin{array}{l}6 \\
13 \\
-\end{array}$ & $\begin{array}{l}18 \\
26 \\
-\end{array}$ & $\begin{array}{l}31,57 \\
68,43 \\
-\end{array}$ \\
\hline \multicolumn{2}{|c|}{$\begin{array}{l}\text { Jumlah } \\
\text { Skor : } 44 / 19=2,3\end{array}$} & 6 & 19 & 44 & 100,00 \\
\hline \multicolumn{6}{|c|}{ Kategori : Cukup Baik } \\
\hline
\end{tabular}

Dari tabel tersebut di atas, menunjukan bahwa kepemimpinan Lurah Lubuk Pakam I-II dalam melengkapi fasilitas kerja dikantor kelurahan, termasuk kategori cukup baik dengan skor 2,31. Jadi dapat dikatakan bahwa fasilitas kerja di Kantor Kelurahan Lubuk Pakam I-II dinilai cukup memadai untuk mendukung pelaksanaan tugas-tugas dan pekerjaan.

\section{Pengembangan}

Potensi,

Kepemimpinan Lurah Lubuk Pakam I-II dalam mengembangkan potensi perangkat kelurahan dapat dilihat pada tabel 15 sebagai berikut:
Tabel 15. Tanggapan Responden Mengenai Kepemimpinan Lurah Dalam Mengembangkan Potensi Perangkat Kelurahan

\begin{tabular}{llllll}
\hline No. & $\begin{array}{l}\text { Alternatif } \\
\text { Jawaban }\end{array}$ & $\mathrm{N}$ & $\mathrm{F}$ & $\mathrm{N} \times \mathrm{F}$ & Persentase \\
\hline 1. & Baik & 3 & 11 & 33 & 57,89 \\
2. & Cukup Baik & 2 & 8 & 16 & 42,11 \\
3. & Kurang & 1 & - & - & - \\
\hline Jumlah & 6 & 19 & 49 & 100,00 \\
\hline
\end{tabular}
Skor : 49/19=2,57

Kategori : Baik

Sumber: Data Olahan Kuisioner No. 1, 2016

Dari tabel di atas, terlihat bahwa kepemimpinan Lurah Lubuk Pakam I-II dalam mengembangkan potensi kerja perangkat kelurahannya, termasuk dalam kategori baik dengan skor 2,57

Pemberian Hukuman atau Sanksi, Kepemimpinan Lurah Lubuk Pakam I-II dalam memberikan hukuman atau sanksi yang tegas dan adil kepada perangkat kelurahannya yang melanggar peraturan, dapat dilihat pada tabel 16. sebagai berikut :

Tabel 16. Tanggapan Responden Mengenai Kepemimpinan Lurah Dalam Menciptakan Hukuman Yang Tegas Dan Adil

\begin{tabular}{|c|c|c|c|c|c|}
\hline No. & $\begin{array}{l}\text { Alternatif } \\
\text { Jawaban }\end{array}$ & $\mathrm{N}$ & $\mathrm{F}$ & $\mathrm{N} \times \mathrm{F}$ & Persentase \\
\hline $\begin{array}{l}1 . \\
2 . \\
3 .\end{array}$ & $\begin{array}{l}\text { Baik } \\
\text { Cukup Baik } \\
\text { Kurang }\end{array}$ & $\begin{array}{l}3 \\
2 \\
1\end{array}$ & $\begin{array}{l}1 \\
4 \\
5 \\
-\end{array}$ & $\begin{array}{l}42 \\
10 \\
-\end{array}$ & $\begin{array}{l}73,68 \\
26,32 \\
-\end{array}$ \\
\hline \multicolumn{2}{|c|}{ Jumlah } & 6 & $\begin{array}{l}1 \\
9\end{array}$ & 52 & 100,00 \\
\hline
\end{tabular}

Skor : $44 / 19=2,74$

Kategori : Baik

Sumber: Data Olahan Kuisioner No. 1, 2016

Dari tabel di atas, terlihat bahwa Kepemimpinan Lurah Lubuk Pakam I-II dalam memberi hukuman atau sanksi kepada perangkat kelurahannya, termasuk dalam kategori baik dengan skor 2,74.

Setelah memperhatikan kepemimpinan Lurah Lubuk Pakam I-II dalam memberikan motivasi kepada perangkat kelurahannya, maka dapat dijelaskan bahwa Lurah sudah dapat dikatakan baik di dalam memotivasi kerja perangakat kelurahannya. 
Tabel 17. Rekapitulasi Hasil Tanggapan

Responden Tentang Kepemimpinan Lurah Dalam Meningkatkan Motivasi Kerja Perangkat Kelurahan

\begin{tabular}{|c|c|c|c|}
\hline No & Variabel & Indikator & Skor \\
\hline 1 & $\begin{array}{l}\text { Kepemimpi } \\
\text { nan Lurah }\end{array}$ & $\begin{array}{l}\text { Meningkatkan } \\
\text { Kesejahteraan } \\
\text { Perangkat } \\
\text { Kelurahan } \\
\text { Menciptakan } \\
\text { suasana kerja yang } \\
\text { harmonis } \\
\text { Memberikan } \\
\text { penghargaan atas } \\
\text { prestasi kerja. } \\
\text { Bersikap Adil } \\
\text { Menghormati dan } \\
\text { Mengikut } \\
\text { sertakan. } \\
\text { Melengkapi } \\
\text { Fasilitas Kerja } \\
\text { Mengembangkan } \\
\text { Potensi } \\
\text { Pemberian } \\
\text { Hukuman }\end{array}$ & $\begin{array}{l}2,84 \\
2,31 \\
2,57 \\
2,74\end{array}$ \\
\hline
\end{tabular}

\begin{tabular}{|c|c|}
\hline Total Skor & 21,12 \\
\hline
\end{tabular}

Sumber: Data Hasil pengolahan Kuisioner Nomor 1 - 8, 2016

Berdasarkan tabel di atas, secara umum diketahui bahwa variabel kepemimpinan Lurah dalam meningkatkan motivasi kerja perangkat kelurahan berdasarkan 8 indikator termasuk dalam kategori baik yaitu dengan skor rata-rata 2,64.

Lurah sebagai penyelenggara pemerintahan, pembangunan dan pembinaan kemasyarakatan di Kelurahan Lubuk Pakam III harus mampu menggerakkan semua pihak baik unsur pemerintahan maupun masyarakat untuk berperan dalam proses pembangunan di Kelurahan Lubuk Pakam I-II.

Secara garis besar kepemimpinan yang telah dan akan dilakukan Lurah di Kelurahan Lubuk Pakam I-II adalah sebagai berikut: 1) Melakukan Rapat Koordinasi antara Muspika dan Dinas Instansi secara rutin minimal $2 \mathrm{x}$ sebulan dan ditambah bila diperlukan untuk membangun komunikasi dengan kegiatan evaluasi dan rencana kerja. 2) Mengadakan bimbingan dan pengarahan setiap hari Senin kepada seluruh Perangkat Kelurahan. 3) Melakukan pembinaan secara terus menerus kepada Perangkat Kelurahan dan menerapkan sanksi teguran mulai dari lisan, tertulis sampai dengan penjatuhan hukuman sesuai PP No. 53 Tahun 2010 tentang Disiplin Pegawai Negeri Sipil. 4) Menciptakan acara-acara informal seperti arisan bulanan, hiburan pada hari libur dengan tujuan mempererat hubungan emosional antar pegawai. 5) Menciptakan suasana manajemen terbuka dengan membangun saluran komunikasi yang lancar dengan memperhatikan dan peduli.

Sedangkan langkah-langkah yang telah dan akan dilakukan oleh Lurah Lubuk Pakam III dalam pembinaan bagi aparatur Kelurahan adalah sebagai berikut: 1) Melaksanakan apel pagi dan siang, 2) Melakukan pembinaan melalui rapat-rapat dinas. 3) Mendorong pegawai rasa memiliki. 4) Menerapkan pengawasan melekat. 5) Melakukan monitoring dari ruangan ke ruangan. 6) Memberikan penghargaan baik moril maupun materil bagi pegawai yang berprestasi. 7) Menerapkan sanksi mulai dari teguran lisan, tulisan sampai pada penerapan hukuman sesuai PP No. 53 Tahun 2010 tentang Disiplin Pegawai Negeri Sipil.

Dari hasil analisis penulis, penulis menggunakan delapan indikator untuk menilai kepemimpinan Lurah Lubuk Pakam I-II. Kepemimpinan Lurah dalam meningkatkan motivasi kerja perangkat kelurahan telah dilaksanakan dengan rata-rata kategori baik dengan (skore rata-rata 2,64) meliputi: 1) Kepemimpinan lurah dalam meningkatkan kesejahteraan telah dilaksanakan dengan kategori baik dengan (skore 2,68) sesuai tabel 9. 2) Kepemimpinan lurah dalam menciptakan suasana kerja yang harmonis telah dilaksanakan dengan kategori baik dengan (skore 2,63 sesuai tabel 10. 3) Kepemimpinan lurah dalam memberikan penghargaan atas prestasi telah dilaksanakan dengan kategori baik dengan (skore 2,57) sesuai tabel 11.4) Kepemimpinan lurah dalam memberikan 
keadilan telah dilaksanakan dengan kategori baik dengan (skore 2,78) sesuai tabel 12 .

Kepemimpinan Lurah dalam menghormati da mengikutsertakan aparat kecamatan telah dilaksanakan dengan kategori baik dengan (skore 2,84) sesuai dengan tabel 13.

Kepemimpinan lurah dalam melengkapi fasilitas kerja telah dilaksanakan dengan kategori cukup baik dengan (skore 2,31) sesuai dengan tabel 14 .

Kepemimpinan lurah dalam mengembangkan potensi aparat kecamatan telah dilaksanakan dengan kategori baik dengan (skore 2,57) sesuai dengan tabel 15.

Kepemimpinan lurah dalam menciptakan hukuman yang tegas dan adil telah dilaksanakan dengan kategori baik dengan (skore 2,74) sesuai dengan tabel 16.

Seorang pegawai dikatakan termotivasi, apabila sikap dan tingkah laku pegawai tersebut telah menunjukkan adanya perubahan kearah yang lebih baik. Misalnya dalam hal disiplin kerja, dan hasil pelaksanaan kerja.

Berdasarkan hasil pengamatan penulis di Kelurahan Lubuk Pakam I-II, diperoleh keterangan bahwa tingkat motivasi kerja perangkat kelurahan sudah cukup baik akan tetapi harus lebih ditingkatkan. Hal ini dapat diketahui dari hasil pelaksanaan kerja perangkat kelurahan.

Tabel 18. Tanggapan Responden Mengenai Tingkat Disiplin Kerja Perangkat Kelurahan

\begin{tabular}{|c|c|c|c|c|c|}
\hline $\begin{array}{l}\mathrm{N} \\
\mathrm{o} .\end{array}$ & $\begin{array}{l}\text { Alternatif } \\
\text { Jawaban }\end{array}$ & $\mathrm{N}$ & $\mathrm{F}$ & $\begin{array}{l}\mathrm{Nx} \\
\mathrm{F}\end{array}$ & $\begin{array}{l}\text { Persentas } \\
\mathrm{e}\end{array}$ \\
\hline 1. & Baik & 3 & 7 & 21 & 36,84 \\
\hline 2. & Cukup Baik & 2 & 9 & 18 & 47,37 \\
\hline 3. & Kurang & 1 & 3 & 3 & 15,79 \\
\hline & & 6 & 19 & 42 & 100,00 \\
\hline \multicolumn{6}{|c|}{ Skor : $42 / 19=2,21$} \\
\hline
\end{tabular}

Sumber: Data Olahan Kuisioner No. 1, 2016

Dari tabel tersebut, terlihat bahwa tingkat disiplin kerja perangkat di Kelurahan Lubuk Pakam I-II termasuk dalam kategori cukup baik dengan skor 2,21.
Disiplin kerja adalah kesadaran dan kesediaan dari seorang pegawai untuk mematuhi segala peraturan yang ada. Disiplin kerja itu sebenarnya sudah dimiliki oleh setiap perangkat, hanya tergantung cara membina dan menegakkannya. Disini dibutuhkan peranan seorang lurah untuk bisa mengarahkan pegawainya agar bisa mentaati aturan yang berlaku, dalam arti menumbuhkan cara bersaing yang sehat, sehingga para pegawai berlomba untuk maju bukan berdasarkan atas dekat atau jauhnya hubungan pribadi pegawai dengan atasan tetapi berdasarkan hasil kerjanya.

Disiplin pegawai Kelurahan Lubuk Pakam I-II dalam bekerja dianggap cukup baik, hal ini dapat dilihat dari daftar absensi yang ada, dimana absensi yang dilakukan setiap 2 kali sehari yaitu pada saat apel pagi dan apel siang dan itu sesuai dengan aturan yang berlaku. Pengecekan yang dilakukan pada saat apel tersebut, kadang terhambat karena ada perangkat yang terlambat datang atau bahkan tidak hadir, hal tersebut membutuhkan kebijaksanaan dari Lurah apakah termasuk pelanggaran disiplin atau karena faktor ketidaksengajaan. Tetapi sudah menjadi kebiasaan aparat kelurahan untuk meminta ijin lisan atau tulisan terlebih dahulu bila berhalangan hadir baik karena kepentingan yang mendesak, sakit dan sebagainya sehingga keterangan itu jelas.

Berdasarkan hasil wawancara penulis dengan Bapak Budiaman Sagala selaku Sekretaris Lurah Lubuk Pakam I-II pada tanggal 21 April 2016 di Kantor kelurahan Lubuk Pakam I-II, diperoleh keterangan bahwa disiplin kerja Lurah beserta perangkat Kelurahan Lubuk Pakam I-II sudah cukup baik. Sebab Lurah dan sebagian besar perangkat kelurahan telah berusaha untuk mematuhi segala peraturan yang berlaku, misalnya berusaha untuk datang dan pulang kerja tepat pada waktunya, berusaha untuk selalu masuk kerja, dan meminta izin apabila tidak masuk kerja. 
Hasil pekerjaan seseorang dikatakan baik, apabila orang tersebut dapat memberikan manfaat atau keuntungan, tidak menghabiskan banyak biaya, dan selesai sesuai dengan rencana atau tepat waktu.

Berdasarkan hasil pengamatan penulis pada tanggal 21 April 2016 sampai dengan 27 Mei 2016 di Kelurahan Lubuk Pakam I-II, diperoleh keterangan bahwa hasil pelaksanaan pekerjaan perangkat kelurahan cukup baik sebab sebagian besar mereka menyelesaikan pekerjaannya dengan tepat waktu melayani masyarakat dengan baik, sehingga masyarakat menjadi puas dan melaksanakan pekerjaannya sesuai dengan petunjuk yang telah ditetapkan, memberikan pelayanan diluar jam kerja, bersikap ramah, tidak meminta imbalan kecuali dengan adanya pemberian sukarela.

Hasil pelaksanaan pekerjaan yang dilakukan oleh perangkat kelurahan di Kelurahan Lubuk pakam I-II, dapat di lihat pada tabel 19. sebagai berikut :

Tabel 19. Tanggapan Responden Mengenai

Hasil Pelaksanaan Pekerjaan Perangkat Kelurahan
Untuk hasil rekapitulasi dari tanggapan responden tentang kepemimpinan Lurah dalam meningkatkan motivasi kerja perangkat kelurahan akan dijelaskan pada tabel 20 . berikut ini :

Tabel 20. Rekapitulasi Hasil Tanggapan Responden Tentang Tingkat Motivasi Kerja Perangkat Kelurahan.

\begin{tabular}{|c|c|c|c|}
\hline $\mathrm{N}$ & Variabel & Indikator & Skor \\
\hline \multirow[t]{2}{*}{1} & Tingkat & Disiplin & 2,21 \\
\hline & $\begin{array}{l}\text { Motivasi Kerja } \\
\text { Perangkat } \\
\text { Kelurahan }\end{array}$ & $\begin{array}{l}\text { kerja } \\
\text { Hasil } \\
\text { pekerjaan }\end{array}$ & 2,10 \\
\hline \multicolumn{3}{|c|}{ Total Skor } & 4,31 \\
\hline & $31 / 2=$ & & \\
\hline
\end{tabular}

Sumber: Data Hasil pengolahan Kuisioner Nomor 9 - 10, 2016

Berdasarkan tabel dan tabel di atas, secara umum diketahui bahwa variabel motivasi kerja perangkat kelurahan di kantor Kelurahan Lubuk Pakam I-II termasuk dalam kategori cukup baik yaitu dengan skor ratarata 2,15. Hal ini menunjukan bahwa pada Variabel tingkat motivasi kerja perangkat kelurahan di kantor Kelurahan Lubuk Pakam I-

\begin{tabular}{llllll}
\hline No. & $\begin{array}{l}\text { Alternatif } \\
\text { Jawaban }\end{array}$ & $\mathrm{N}$ & $\mathrm{F}$ & $\mathrm{N} \times \mathrm{F}$ & Persentas \\
\hline 1. & Baik & 3 & 6 & 18 & 31,57 \\
2. $\quad$ Cukup Baik & 2 & 9 & 18 & 47,37 \\
3. $\quad$ Kurang & 1 & 4 & 4 & 21,06 \\
\hline Jumlah & 6 & 19 & 40 & 100,00 \\
\hline \multicolumn{2}{l}{ Skor : 40/19=2,10 } \\
Kategori : Cukup Baik
\end{tabular}

Sumber: Data Olahan Kuisioner No. 1, 2016

Dari tabel di atas, terlihat bahwa hasil pelaksanaan pekerjaan yang dilakukan oleh perangkat Kelurahan Lubuk Pakam I-II termasuk dalam kategori cukup baik dengan skor 2,10.

Disamping pemberian kuesioner, penulis juga mewawancarai responden, responden yang dimaksud adalah Lurah yang mengatakan bahwa hasil pelaksanaan pekerjaan dari perangkat Kelurahan Lubuk Pakam I-II adalah baik, dengan alasan dalam pemberian pelayanan kepada masyarakat adanya transparansi, bersikap ramah, pelayanan tepat waktu yang telah disepakati

\section{Kesejahteraan} Perangkat Kelurahan, peningkatan kesejahteraan perangkat merupakan salah satu upaya yang dilakukan oleh Lurah Lubuk Pakam I-II dalam rangka meningkatkan motivasi perangkat hal tersebut sejalan dengan penuturan Kepala Seksi Trantib Lubuk Pakam I-II Bapak Jumino, SE pada tanggal 22 April 2016, Untuk menambah tingkat kesejahteraan bawahannya Lurah Lubuk Pakam I-II melakukan upaya-upaya diantaranya dengan mendirikan koperasi simpan pinjam, agar perangkat kelurahan memperoleh modal untuk membuka usaha yang dapat menambah penghasilannya, memberikan kesempatan untuk mengikuti diklat yang dapat mempercepat karier perangkat yang bersangkutan, serta memberikan tunjangan kesejahteraan seperti tunjangan hari raya dan tunjangan untuk perangkat yang sakit, memberikan kebebasan 
Yang bertanggung jawab dalam pekerjaan, menerima masukan atau saran sesama perangkat kelurahan.

Menciptakan suasana kerja yang harmonis, dalam rangka menghindari kejenuhan perangkat kelurahan di Kelurahan Lubuk Pakam I-II maka dibutuhkan suasana kerja yang harmonis agar para perangkatnya betah dan tidak jenuh dalam melaksanakan tugasnya. Hal tersebut sejalan dengan penuturan Bapak Jumino, SE selaku Kepala Seksi Trantib Lubuk Pakam I-II pada tanggal 25 April 2004, diperoleh keterangan bahwa suasana yang harmonis antara lurah dengan perangkat kelurahan di lingkungan organisasi kelurahan sangat baik. Hal ini disebabkan karena lurah dan perangkat kelurahan menyadari bahwa dengan adanya kerja sama yang harmonis, maka motivasi kerja perangkat kelurahan dapat meningkat. Upaya-upaya yang telah dilakukan oleh lurah di Kelurahan Lubuk Pakam I-II diantaranya adalah dengan penataan ruang kerja sehingga lebih rapi dan nyaman, membangun tempat ibadah yang tenang, mengutamakan musyawarah dalam menyelesaikan permasalahan agar tercipta rasa kekeluargaan dan saling menghargai, dan menjalin komunikasi yang aktif antara lurah dengan perangkat kelurahan dan antara sesama perangkat kelurahan itu sendiri.

Memberikan penghargaan atas prestasi kerja, salah satu faktor yang dapat mempengaruhi motivasi kerja perangkat kelurahan dalam melaksanakan tugasnya adalah diterimanya penghargaan atas hasil kerja yang dilakukannya, maka dari itu lurah selalu memberikan penghargaan atas jerih payah yang dilakukan oleh perangkatnya. Hal itu sejalan dengan penuturan Bapak Bambang Hermanto, SH selaku Kepala Seksi Pemerintahan Lubuk Pakam I-II pada tanggal 26 April 2016, diperoleh keterangan bahwa lurah telah berupaya untuk memotivasi kerja perangkat kelurahan melalui pemberian penghargaan kepada pegawai kelurahan yang berprestasi. Penghargaan yang diberikan diantaranya memberikan pujian yang dinyatakan dengan lisan pada saat apel, memberikan pujian yang dinyatakan lewat piagam, mempromosikan pegawai untuk kenaikan pangkat dan jabatan. Walaupun bentuk penghargaan yang diberikan tersebut terkadang hanya berupa ucapan terima kasih, pujian atau pengakuan secara wajar terhadap keberhasilan yang telah dicapai, namun upaya tersebut cukup berhasil dalam menumbuhkan motivasi kerja dan rasa bangga dari dalam diri perangkat kelurahan untuk selalu berusaha meningkatkan hasil kerja yang akan dicapai. Karena di samping itu keberhasilan yang dicapai akan menjadi catatan sebagai atasan langsung terhadap prestasi kerja dalam DP-3.

Bersikap Adil, keadilan yang merata tanpa memandang satus sosial seseorang dapat membuat perangkat kelurahan yang bekerja di Kelurahan Lubuk Pakam I-II merasa dihargai sehingga menimbulkan motivasi kerja perangkat cukup tinggi, maka dari itu Lurah Lubuk Pakam I-II selalu memperlakukan perangkatnya secara adil. Hal tersebut sesuai dengan penuturan Bapak Budiaman Sagala selaku Sekretaris Lurah Lubuk Pakam I-II pada tanggal 26 april 2016 diperoleh keterangan bahwa Lurah sendiri telah berupaya bersikap adil terhadap seluruh perangkat kelurahannya, karena lurah menyadari bahwa keadilan adalah suatu hal yang penting dalam meningkatkan motivasi kerja perangkat kelurahannya. Dengan keadilan, perangkat kelurahan akan merasa dihargai hak asasinya, dan akhirnya timbul kesadaran dan semangat untuk melaksanakan tugas-tugasnya dengan baik. Keadilan yang diberikan diantaranya keadilan pemberian sanksi atau hukuman, didalam mempromosikan kenaikan pangkat perangkat kelurahan, dalam memberikan penilaian pelaksanaan pekerjaan, dan lain sebagainya.

Menghormati dan Mengikutsertakan., dalam kepemimpinannya Lurah Lubuk Pakam I-II selalu menghormati dan mengikutsertakan perangkatnya untuk mengambil keputusan sehingga perangkat tersebut merasa dihargai dan termotivasi untuk meningkatkan hasil 
pekerjaannya. Hal tersebut sejalan dengan pendapat Bapak Juni Bancin, S.Sos selaku Kepala Seksi Kesejahteraan Sosial Lubuk Pakam I-II pada tanggal 26 April 2016, diperoleh keterangan bahwa Lurrah Lubuk Pakam I-II telah berupaya mengikutsertakan perangkat kelurahan di dalam pengambilan keputusan. Selain itu beliau juga menjamin komunikasi yang aktif dengan semua perangkat dalam rangka menjalin kekeluargaan didalam dan diluar jam dinas. Hal ini dilakukan agar perangkat kelurahan akan merasa dihargai, dihormati dan dibutuhkan sehingga pada akhirnya mereka dalam melaksanakan tugas-tugasnya dengan baik.

\section{Melengkapi Fasilitas Kerja} berdasarkan hasil pengamatan penulis di Kantor Kelurahan Lubuk Pakam I-II pada tanggal 27 April 2016 sampai dengan 29 April 2016, diperoleh data bahwa fasilitas yang tersedia di kelurahan sudah cukup memadai, walaupun disana sini masih perlu adanya beberapa yang perlu tambahkan. Sehingga dalam melaksanakan tugas-tugasnya dapat berjalan dengan cepat dan tepat waktu serta dapat terwujudnya pelayanan yang optimal kepada masyarakat.

Dalam rangka mendukung kinerja perangkat kelurahan Lubuk Pakam I-II diperlukan kelengkapan dari fasilitas kerjanya, karena fasilitas kerja sangat dibutuhkan untuk mendukung kinerja perangkat tersebut. Maka dari itu lurah Lubuk Pakam I-II selalu berusaha untuk melengkapi fasilitas kerja yang ada di Kelurahan Lubuk Pakam I-II. Hal tersebut sejalan dengan penuturan Bapak Budiaman Sagala selaku Sekretaris Lurah Lubuk Pakam III pada tanggal 27 April 2016, diperoleh keterangan bahwa fasilitas kerja yang tersedia di kantor Kelurahan Lubuk Pakam I-II cukup memadai, ini dikarenakan lurah telah berupaya melengkapi fasilitas-fasilitas tersebut. Walaupun dilakukan secara bertahap, hal ini disebabkan keterbatasan dana untuk mencukupi sarana dan prasarana yang lainnya. Upaya-upaya tersebut misalnya mengeluarkan dana untuk melengkapi fasilitas-fasilitas kerja yang paling penting dan paling dibutuhkan.

Upaya yang dilakukan oleh Lurah Lubuk Pakam I-II didalam melengkapi fasilitas kerja di kantor kelurahan antara lain melengkapi sarana kerja yang secara langsung dibutuhkan dalam melakukan pelayanan kepada masyarakat.

Mengembangkan Potensi, lurah Lubuk Pakam I-II berusaha untuk mengembangkan potensi perangkatnya dalam rangka peningkatan kualitas kerja perangkat kelurahan Lubuk Pakam I-II tersebut. Hal tersebut sejalan dengan penuturan Bapak Budiaman Sagala selaku Sekretaris Lurah Lubuk Pakam I-II pada tanggal 28 April 2016, diperoleh data bahwa lurah telah berusaha mengembangkan potensi perangkat kelurahan di Kelurahan Lubuk Pakam I-II. Adapun usaha yang dilakukan Lurah Lubuk Pakam I-II adalah memberikan kesempatan kepada perangkat kelurahan untuk ikut serta dalam pemecahan permasalahan yang ada di kantor Kelurahan Lubuk Pakam I-II, memberikan bimbingan dan petunjuk tentang cara penyelesaian tugas dengan baik, dan memberikan kesempatan kepada perangkat kelurahan yang ingin melanjutkan pendidikan ataupun mengikuti diklat penjenjangan.

Pemberian Hukuman, dalam rangka meningkatkan tingkat disiplin kerja perangkat kelurahan Lubuk Pakam I-II maka Lurah Lubuk Pakam I-II melaksanakan penerapan hukuman bagi perangkatnya yang tidak disiplin. Hal tersebut sejalan dengan penuturan Bapak Budiaman Sagala selaku Sekretaris Lurah Lubuk Pakam I-II pada tanggal 28 April 2016, diperoleh keterangan bahwa Lurah Lubuk Pakam I-II telah berupaya memberikan hukuman atau sanksi berdasarkan keadilan, yaitu sesuai dengan kesalahan yang diperbuat oleh perangkat tersebut. Hal ini dilakukan lurah dalam rangka meningkatkan motivasi kerja perangkat kelurahannya. Sebab dengan memberikan hukuman atau sanksi secara tegas dan adil, 
perangkat akan merasa diakui hak asasinya, dan diperlakukan sama dengan perangkat lainnya, sehingga mereka terdorong untuk melaksanakan tugas-tugasnya dengan baik. Setelah memperhatikan upaya Lurah Lubuk Pakam I-II dalam memberikan motivasi kepada perangkat kelurahannya, maka dapat dijelaskan bahwa lurah Lubuk Pakam I-II sudah dapat dikatakan baik di dalam memotivasi kerja perangkat kelurahannya dan tingkat motivasi kerja perangkat kelurahannya juga sudah optimal

\section{SIMPULAN}

Kepemimpinan Lurah di dalam memotivasi kerja perangkat kelurahan berdasarkan penghitungan dari nilai dari 8 indikator mendapatkan skor rata-rata 2,64 yang dikategorikan baik, sehingga dapat disimpulkan bahwa kepemimpinan Lurah Lubuk Pakam I-II dalam memotivasi kerja perangkat kelurahannya termasuk dalam kategori baik, Ini berarti kepemimpinan Lurah Lubuk Pakam I-II telah berjalan secara optimal. Tingkat motivasi kerja perangkat kelurahan di kantor Kelurahan Lubuk Pakam III dapat dilihat dari 2 indikator yaitu: disiplin kerja dan hasil pelaksanaan kerja dimana keduanya telah dilaksanakan dengan kategori cukup baik. Upaya-upaya Lurah dalam meningkatkan motivasi kerja perangkat Kelurahan Lubuk Pakam I-II adalah sebagai berikut : memberikan penghargaan, meningkatkan kesejahteraan perangkat kelurahan, menciptakan suasana kerja yang harmonis, memberikan penghargaan atas prestasi kerja, bersikap adil, menghormati dan mengikutsertakan, melengkapi fasilitas kerja, mengembangkan potensi, pemberian hukuman, memberikan kesempatan untuk mengikuti diklat yang dapat mempercepat karier perangkat yang bersangkutan, serta memberikan tunjangan kesejahteraan seperti tunjangan hari raya dan tunjangan untuk perangkat yang sakit, memberikan kebebasan yang bertanggung jawab dalam pekerjaan, menerima masukan atau saran sesama perangkat kelurahan.

\section{DAFTAR PUSTAKA}

Abraham, M. 2002 dalam buku A Dale Timpe. Seri Manajemen Sumber Daya Manusia (Memotivasi Pegawai). Jakarta: PT. Elek Media Koputindo.

Akbar, A, 2004. Leadership and its Influence in Organizatio. Faculty of Management Information Systems National University of sciences \& Technology, Pakistan.

Atmosudirjo, P. 1999. Teknik Kepemimpinan Modern. Bandung, PT Remaja Rosdakarya.

Arikunto, S, 2002. Prosedur Penelitian, Jakarta : PT Rineka Cipta.

. 2010. Prosedur Penelitian Suatu Pendekatan Praktik, Jakarta : Rineka Cipta.

Benjamin, J.I, 2013. Exploring the Concept of Leadership Derailment. University of Calabar, Nigeria.

Buchari, Z, 1994, Manajemen dan Motivasi, Jakarta: Balai Aksara.

Dessler, G. 2000. Manajemen Sumber Daya Manusia. Edisi ke-7, Alih bahasa, Jilid 1 \& Jilid 2, Jakarta: Prenhallindo.

Fathoni, A, 2006. Manajemen Sumber Daya Manusia, Jakarta: Rineka Cipta, Jakarta.

Gibson L, lvancevich, John M.. James H. Donnely. 1996. Informasi Manajemen (Terjemahan Djoerban Wahid). Jakarta: CV Erlangga.

Gomes, F.C, 2003, Manajemen Sumber Daya Manusia, Andi, Yogyakarta.

Handoko, T.H, 2000, Manajemen Personalia dan Sumber Daya Manusia, BPFE, Yogyakarta.

H. Pasolong, 2013, Kepemimpinan Birokrasi, Yogyakarta, Alfabeta.

Hasibuan, M S.P. 2005, Manajemen Sumber Daya Manusia, CV. Haji Masagung, Jakarta.

J, Kaloh, 2009, Kepemimpinan Kepala Daerah, Jakarta, Sinar Grafika.

Kartono, K, 2011, Pemimpin dan kepemimpinan, Jakarta: Raja Grafindo.

Manullang, M. 2008, Pengantar Ekonomi Perusahaan, Jakarta, Ghalia Indonesia.

Moleong, L.J. 2010, Metodologi Penelitian Kualitatif, Remaja Rosda Karya, Bandung.

Nawawi, H, 2008, Metode Penelitian Bidang Sosial, Yogyakarta, Liberty.

Nazir, M. 1999, Metode Penelitian. Bandung: Tarsioto Tarsioto

Pamudji, S. 1998, Kepemimpinan Pemerintahan Di Indonesia, Jakarta: Bumi Aksara.

Pamudji, S. 1998. Human Relations Pimpinan. Yogjakarta, Andi Offset. 
Bobby Arianto, Warjio, Usman Tarigan, Kepemimpinan Lurah dalam Meningkatkan

Prawirosentono, S. 2015. Mannajemen Sumber Daya Manusia, Kinerja \& Motivasi Karyawan, BPFE Yogyakarta.

Rafikul, I. 2008, Employee Motivation: A Malaysian Perspective, Kuala Lumpur, Malaysia.

Rasyid, M,R., 2000, Makna Pemerintahan:Tinjauan dari segi etika dan kepemimpinan, Jakarta, Mutiara Sumber widya.

Sardiman, A.M, 2004, Interaksi dan Motivasi Belajar Mengajar, Jakarta : PT. Rajagrafindo Persada.

Siagian, S.P., 1996, Teori dan Motivasi dan Aplikasinya, Jakarta : Rineka Cipta. , 2006, Manajemen Sumber Daya Manusia, Jakarta: Erlangga.

Sugiyono, 2010, Metode Penelitian Administrasi. Bandung : Alfabeta.

Sugiyono, 2015, Metode Penelitian dan Pengembangan. Bandung : Alfabeta.

Suradinata, E, 1995. Psikologi Kepegawaian dan Peranan Pemimpin dalam Memotivasi Kerja. Bandung : Ramadan.
Syafiie, I.K., 2013, Pengantar Ilmu Pemerintahan, Rafika Aditama, Bandung.

Vina, C.G., 2008. Motivation In The Workplace To Improve The Employee Performance. Andhra University, Visakhapatnam.

Wahjosumidjo, 1992. Kepemimpinan dan Motivasi. Jakarta : Ghalian Indonesia.

\section{PERATURAN PERUNDANG-UNDANGAN}

Undang-Undang Nomor 23 Tahun 2014 Tentang Pemerintahan Daerah yang dititik beratkan kepada Daerah Kabupaten dan Kota.

Peraturan Pemerintah Nomor 53 Tahun 2010 tentang Disiplin Pegawai Negeri Sipil.

Peraturan Pemerintah Nomor 73 Tahun 2005 Tentang Pedoman Organisasi Perangkat Daerah.

Keputusan Mendagri Nomor 159 Tahun 2004 Tentang Pedoman Organisasi Kelurahan.

Peraturan Daerah Kabupaten Deli Serdang Nomor 05 Tahun 2007 Tentang Pembentukan, Susunan Organisasi dan Tata Kerja Perangkat Daerah. 